\title{
Synthesis and Thermodynamic Studies of Oligodeoxyribonucleotides Containing Tandem Lesions of Thymidine Glycol and 8-0xo-2'-Deoxyguanosine
}

\author{
Yuesong Wang and Yinsheng Wang ${ }^{*}$ \\ Department of Chemistry-027, University of California at Riverside, Riverside, CA 92521-0403
}

\begin{abstract}
Thymidine glycol (Tg), which is also known as 5,6-dihydroxy-5,6-dihydrothymidine, and 8-oxo-7,8dihydro-2'-deoxyguanosine (8-oxodG) are two major types of DNA damage products induced by reactive oxygen species (ROS). Here we report the synthesis of oligodeoxyribonucleotides (ODNs) containing both $\mathrm{Tg}$ and 8-oxodG. The dual incorporation of the two single-base lesions was achieved by using a phosphoramidite building block of 8-oxodG with ultramild base protecting group and a building block of $\mathrm{Tg}$ whose nucleobase hydroxyl groups were protected with acetyl functionality. The availability of ODNs carrying neighboring 8-oxodG and Tg provided authentic substrates for assessing the formation and examining the replication and repair of this kind of tandem lesions. In addition, thermodynamic parameters derived from melting temperature data revealed that tandem lesions destabilized the double helix to a greater extent than either of the two single-base lesions alone. The thermodynamic results could offer a basis for understanding the repair of the tandem base lesions.
\end{abstract}

\section{Introduction}

Reactive oxygen species (ROS) can lead to a plethora of modifications to DNA, which yield nucleobase and deoxyribose lesions, strand breaks, and DNA-protein cross-links $(1,2)$. These oxidative DNA lesions may have implications in a variety of pathological conditions, including diseases associated with aging and cancer $(1,3)$. Thymidine glycol (or 5,6-dihydroxy-5,6dihydrothymidine, $\mathrm{Tg}$ ) and 8-oxo-7,8-dihydro-2'-deoxyguanosine (8-oxodG) are two common monomeric base lesions induced by ROS. Thymidine glycol lacks mutagenicity under most conditions (4-7). However, it effectively blocks DNA replication (8,9). By contrast, 8-oxodG is a major mutagenic lesion and can result in $\mathrm{G} \rightarrow \mathrm{T}$ transversion mutation $(10,11)$.

In recent years, several types of tandem DNA lesions (12-20), where damage involves two adjacent nucleosides, have been isolated and characterized. A first example of tandem lesions, with a 8-oxodG and a formamido $(\mathrm{d} \beta \mathrm{F})$ residue being neighboring to each other, was reported by Box et al. $(12,21)$. Recently Bourdat et al. (15) showed that the amount of these tandem lesions, $\mathrm{d} \beta \mathrm{F}$-8-oxodG and its isomeric 8-oxodG- $\mathrm{d} \beta \mathrm{F}$, formed from $\gamma$ radiation cannot account for the total amount of tandem lesions involving 8-oxodG. It was, therefore, postulated that other tandem lesions involving 8-oxodG may exist. Since thymidine glycol and 8-oxodG are major types of single-nucleobase lesions induced by ROS (2), we reason that tandem lesions with a 8-oxodG being adjacent to a Tg might be induced by ROS.

\footnotetext{
*Address correspondence to: Yinsheng Wang, E-mail: yinsheng.wang@ucr.edu, Fax: (951)827-4713, Tel: (951)827-2700
} 
Clustered DNA damages, in which two or more lesions within one or two helical turns of the DNA helix, can be initiated from a single ionizing radiation track (22-24). It has been shown that such damaged sites were difficult to be repaired with purified repair enzymes and in mammalian cells (25-31). To understand the biological significances of tandem lesions with a $\mathrm{Tg}$ being neighboring to an 8-oxodG, it is crucial to assess their formation and to examine the replication and repair of this type of lesions. The lack of procedures for preparing pure and sufficient tandem lesion-bearing substrates, however, hampers such studies. This motivates us to design synthetic approaches for the incorporation of both types of lesions into oligodeoxyribonucleotides (ODNs).

Solid-phase synthesis of ODNs by using phosphoramidite building blocks is advantageous over the post-synthetic methods for the preparation of modified or damaged ODNs because the chain length and the sequence are not restricted and large-scale preparation is available (32). In this regard, Iwai $(33,34)$ described the synthesis of a building block of thymidine glycol where the nucleobase hydroxyl group(s) were protected with tert-butyldimethylsilyl (TBDMS) group. Very recently, Cadet et al. (35) reported the synthesis of a Tg building block where the nucleobase hydroxyl group(s) was protected with a base-labile levulinyl functionality. On the other hand, the deprotection of ODNs synthesized from the commercially available building block of 8-oxodG requires prolonged treatment with concentrated ammonium hydroxide; during such treatment, thymidine glycol, however, was shown to be significantly degraded (33). Therefore, dual insertion of 8-oxodG and thymidine glycol necessitates alternative synthetic strategies.

Here in this paper we reported the successful preparation of ODN substrates bearing both 8oxodG and $\mathrm{Tg}$, which provides substrates for examining the formation of the tandem lesions with neighboring 8-oxodG and Tg induced by ROS. The availability of this type of substrates also facilitates the investigation of the replication and repair of this type of lesions both in vitro and in vivo.

\section{Experimental Section}

\section{Materials}

Common reagents for solid-phase DNA synthesis were obtained from Glen Research Co. (Sterling, VA). Unmodified ODNs used in this study were purchased from Integrated DNA Technologies (Coraville, IA). Silica gel and TLC plates were obtained from EM Science (Gibbstown, NJ). All chemicals unless otherwise specified were from Sigma-Aldrich (St. Louis, MO).

\section{Mass Spectrometry}

Electrospray ionization-mass spectrometry (ESI-MS) and tandem MS (MS/MS) experiments were carried out on an LCQ Deca XP ion-trap mass spectrometer (ThermoFinnigan, San Jose, CA). An equal-volume solvent mixture of acetonitrile and water was used as solvent for electrospray, and a $2-\mu \mathrm{L}$ aliquot of $\sim 5 \mu \mathrm{M}$ sample solution was injected in each run. The spray voltage was $3.4 \mathrm{kV}$ and the instrument was operated in the negative-ion mode.

\section{HPLC}

A 4.6×250 mm Apollo C18 column ( $5 \mu \mathrm{m}$ in particle size, $300 \AA \AA$ in pore size, Alltech Associate Inc., Deerfield, IL) was used for the separation of synthetic ODNs. A solution of $50 \mathrm{mM}$ triethylammonium acetate (TEAA, solution A) and a mixture of $50 \mathrm{mM}$ TEAA and acetonitrile $(70 / 30, v / v$, solution B) were used as mobile phases. The flow rate was $0.8 \mathrm{~mL} / \mathrm{min}$, and a gradient of $5 \min 0-20 \%$ B, $45 \min 20-50 \%$ B and $5 \min 50-100 \%$ B was employed. 


\section{Synthesis and Characterization of Compounds (Scheme 1)}

3',5'-O-(4,4'-dimethoxytrityl)thymidine (1)—The title compound was synthesized according to the procedures reported by Sekine et al. (36). In this respect, it is worth mentioning that the incorporation of the bulky 4,4'-dimethoxytrityl (DMTr) functionality to the 3 '-hydroxyl group required a reaction temperature of $70{ }^{\circ} \mathrm{C}(36)$, though the traditional DMTr protection of the 5'-hydroxyl group is typically carried out at room temperature. Yield: $6.79 \mathrm{~g} \mathrm{(97 \% ).}$

$\mathrm{R}_{\mathrm{f}}: 0.38$ (EtOAc-hexane, 1:1). ${ }^{1} \mathrm{H}$ NMR (400 MHz, DMSO- $\left.d_{6}\right): \delta 11.30$ (br, $\left.1 \mathrm{H}\right), 6.75-7.37$ $(\mathrm{m}, 26 \mathrm{H}), 6.15(\mathrm{~m}, 1 \mathrm{H}), 4.21(\mathrm{~m}, 1 \mathrm{H}), 3.94(\mathrm{~m}, 1 \mathrm{H}), 3.70(\mathrm{~s}, 6 \mathrm{H}), 3.68(\mathrm{~d}, J=3.2 \mathrm{~Hz}, 6 \mathrm{H})$, $3.00(\mathrm{~m}, 1 \mathrm{H}), 2.92(\mathrm{~m}, 1 \mathrm{H}), 1.77(\mathrm{~m}, 1 \mathrm{H}), 1.61(\mathrm{~m}, 1 \mathrm{H}), 1.36(\mathrm{~s}, 3 \mathrm{H})$. MALDI-MS: $\mathrm{m} / \mathrm{z} 869.1$ $[\mathrm{M}+\mathrm{Na}]^{+}$.

(5R,6S)-3',5'-0-(4,4'-dimethoxytrityl)thymidine glycol (2)—Compound $\mathbf{1}$ (1.67 g, $1.97 \mathrm{mmol})$ and $\mathrm{OsO}_{4}(0.5 \mathrm{~g}, 1.97 \mathrm{mmol})$ were dissolved in pyridine $(7.5 \mathrm{~mL})$, and the mixture was stirred at room temperature for $2 \mathrm{~h}$. Sodium hydrogen sulfite $(1.8 \mathrm{~g})$, dissolved in a mixture of water $(30 \mathrm{~mL})$ and pyridine $(20 \mathrm{~mL})$, was then added to the reaction mixture. The mixture was stirred for another $2 \mathrm{~h}$. The product was extracted twice with $\mathrm{CHCl}_{3}(150 \mathrm{~mL})$ and the organic layer was dried with $\mathrm{Na}_{2} \mathrm{SO}_{4}$. The solvent was removed under reduced pressure. The reaction mixture was then loaded onto a silica gel column and eluted with a $\mathrm{CH}_{2} \mathrm{Cl}_{2}$ solution containing $0.5 \% \mathrm{MeOH}$ and $0.1 \% \mathrm{Et}_{3} \mathrm{~N}$. Yield: $1.17 \mathrm{~g}(67 \%) . \mathrm{R}_{\mathrm{f}}: 0.24\left(\mathrm{CH}_{3} \mathrm{OH}-\mathrm{CH}_{2} \mathrm{Cl}_{2}\right.$, 1:19). ${ }^{1} \mathrm{H}$ NMR $\left(300 \mathrm{MHz}, \mathrm{CDCl}_{3}\right): \delta 6.77-7.50(\mathrm{~m}, 26 \mathrm{H}), 6.29(\mathrm{~m}, 1 \mathrm{H}), 5.09(\mathrm{~s}, 1 \mathrm{H}), 4.44$ $(\mathrm{m}, 1 \mathrm{H}), 3.92(\mathrm{~m}, 1 \mathrm{H}), 3.79(\mathrm{~m}, 12 \mathrm{H}), 3.02(\mathrm{~m}, 2 \mathrm{H}), 2.05(\mathrm{~m}, 1 \mathrm{H}), 1.77(\mathrm{~m}, 1 \mathrm{H}), 1.28(\mathrm{~s}, 3 \mathrm{H})$. MALDI-MS: $m / z 903.4[\mathrm{M}+\mathrm{Na}]^{+}$.

\section{(5R,6S)-3',5'-0-(4,4'-dimethoxytrityl)-5,6-O-acetyl-thymidine glycol (3)-}

Compound $2(281 \mathrm{mg}, 0.32 \mathrm{mmol})$ was coevaporated twice with dry pyridine $(10 \mathrm{~mL})$ and the dried residue was dissolved again in dry pyridine $(2 \mathrm{~mL})$. DMAP (4-dimethylaminopyridine, $7.38 \mathrm{mg}, 0.06 \mathrm{mmol})$ and acetic anhydride $(0.36 \mathrm{~mL}, 3.84 \mathrm{mmol})$ were added into the solution under argon atmosphere. After $15 \mathrm{~h}$, the solution was dried under reduced pressure, and the dried residue was redissolved in EtOAc $(80 \mathrm{~mL})$. The organic layer was washed with water (twice, $40 \mathrm{~mL}$ ) and brine ( $40 \mathrm{~mL}$ ), dried over $\mathrm{Na}_{2} \mathrm{SO}_{4}$, and concentrated. Glycol 3 (262 mg, $82 \%$ ) was isolated with a silica gel column using a solvent gradient of 0-15\% EtOAc in $\mathrm{CH}_{2} \mathrm{Cl}_{2} . \mathrm{R}_{\mathrm{f}}: 0.58$ (EtOAc- $\left.\mathrm{CH}_{2} \mathrm{Cl}_{2}, 15: 85\right) .{ }^{1} \mathrm{H}$ NMR $\left(400 \mathrm{MHz}, \mathrm{CDCl}_{3}\right): \delta 8.64(\mathrm{~s}, 1 \mathrm{H})$, 7.15-7.40 (m, 18H), 6.69-6.81 (m, 8H), $6.35(\mathrm{~s}, 1 \mathrm{H}), 6.03(\mathrm{dd}, 1 \mathrm{H}, J=5.8,8.7 \mathrm{~Hz}), 4.26(\mathrm{~m}$, $1 \mathrm{H}), 4.10(\mathrm{~m}, 3 \mathrm{H}), 3.76(\mathrm{~s}, 6 \mathrm{H}), 3.72(\mathrm{~d}, J=2.3 \mathrm{~Hz}, 6 \mathrm{H}), 3.22(\mathrm{~m}, 2 \mathrm{H}), 2.02(\mathrm{~s}, 3 \mathrm{H}), 2.00(\mathrm{~s}$, 3H), $1.90(\mathrm{~s}, 3 \mathrm{H})$. MALDI-MS: $\mathrm{m} / z$ $987.4[\mathrm{M}+\mathrm{Na}]^{+}$.

(5R,6S)-5,6-O-acetyl-thymidine glycol (4)—Compound 3 (262 mg, $0.27 \mathrm{mmol}$ ) was treated with $70 \%$ acetic acid at room temperature for $6 \mathrm{~h}$. The resulting aqueous solution was dried under reduced pressure. The dried residue was dispersed in ether $(50 \mathrm{~mL})$ and extracted twice with water $(50 \mathrm{~mL}$ each). The aqueous solutions were combined and dried. Yield: $93 \mathrm{mg}$ (95\%). ${ }^{1} \mathrm{H}$ NMR (400 MHz, $\left.\mathrm{CDCl}_{3}\right): \delta 8.86(\mathrm{~s}, 1 \mathrm{H}), 6.91(\mathrm{~s}, 1 \mathrm{H}), 6.09(\mathrm{t}, 1 \mathrm{H}, J=7.3 \mathrm{~Hz}), 4.48$ $(\mathrm{m}, 1 \mathrm{H}), 3.96(\mathrm{~m}, 1 \mathrm{H}), 3.81(\mathrm{~m}, 2 \mathrm{H}), 2.142(\mathrm{~m}, 2 \mathrm{H}), 2.10(\mathrm{~s}, 3 \mathrm{H}), 2.08(\mathrm{~s}, 3 \mathrm{H}), 1.86(\mathrm{~s}, 3 \mathrm{H})$. ESI-MS: $m / z 383.1[\mathrm{M}+\mathrm{Na}]^{+}$.

(5R,6S)-5'-0-(4,4'-dimethoxytrityl)-5,6-O-acetyl-thymidine glycol (5)—Compound $4(90 \mathrm{mg}, 0.26 \mathrm{mmol}$ ) was coevaporated twice with dry pyridine $(5 \mathrm{~mL})$. The dried residue was redissolved in dry pyridine $(2 \mathrm{~mL})$, and to the resulting solution was added 4,4'-

dimethoxytrityl chloride (105 mg, $0.31 \mathrm{mmol})$ under argon atmosphere. After $4 \mathrm{~h}$, the solvent was removed under reduced pressure. The product was loaded onto a silica gel column and eluted with 0-2\% methanol in a solvent mixture of $\mathrm{Et}_{3} \mathrm{~N}$ and $\mathrm{CH}_{2} \mathrm{Cl}_{2}(1: 99, \mathrm{v} / \mathrm{v})$. Yield: 102 mg (61\%). $\mathrm{R}_{\mathrm{f}}: 0.17\left(\mathrm{CH}_{2} \mathrm{Cl}_{2}-\mathrm{CH}_{3} \mathrm{OH}, 19: 1\right) .{ }^{1} \mathrm{H} \mathrm{NMR}\left(400 \mathrm{MHz}, \mathrm{CDCl}_{3}\right): \delta 8.30(\mathrm{~s}, 1 \mathrm{H})$, 7.10-7.46 (m, 9H), 6.81-6.84 (m, 4H), $6.56(\mathrm{~s}, 1 \mathrm{H}), 6.08(\mathrm{t}, 1 \mathrm{H}, J=7.2 \mathrm{~Hz}), 5.27(\mathrm{~s}, 1 \mathrm{H}), 4.35$ 
(m, 1H), $3.42(\mathrm{dd}, 1 \mathrm{H}, J=5.5,9.8 \mathrm{~Hz}), 3.29(\mathrm{dd}, 1 \mathrm{H}, J=5.5,9.8 \mathrm{~Hz}), 2.32(\mathrm{~m}, 1 \mathrm{H}), 2.06(\mathrm{~m}$, 1H), 2.05 (s, 3H), 2.03 (s, 3H), 1.78 (s, 3H). ESI-MS: m/z $685.1[\mathrm{M}+\mathrm{Na}]^{+}$.

(5R,6S)-5'-0-(4,4'-dimethoxytrityl)-5,6-0-acetyl-thymidine glycol-3'-O-[(2cyanoethyl)- $\mathrm{N}, \mathrm{N}$-diisopropyl-phosphoramidite] (6)-To a flask, which was suspended in an ice bath and contained a solution of compound $\mathbf{5}(150 \mathrm{mg}, 226 \mu \mathrm{mol})$ in dry $\mathrm{CH}_{2} \mathrm{Cl}_{2}(1.8$ $\mathrm{mL}$ ), was added $N, N$-diisopropylethylamine (DIEA, $100 \mu \mathrm{L}, 573 \mu \mathrm{mol}$ ) followed by dropwise addition of 2-cyanoethyl- $N, N$-diisopropylchlorophosphoramidite ( $78 \mu \mathrm{L}, 348 \mu \mathrm{mol})$. The mixture was stirred at room temperature for $15 \mathrm{~min}$. A second portion of DIEA (100 $\mu \mathrm{L}, 573$ $\mu \mathrm{mol}$ ) was added to the mixture and the solution was stirred for another $15 \mathrm{~min}$. Workup was carried out by cooling down the mixture in an ice bath followed by addition of $\mathrm{CH}_{3} \mathrm{OH}(0.36$ $\mathrm{mL})$. The solution was quickly extracted with EtOAc $(10 \mathrm{~mL})$ and the organic layer was washed with $\mathrm{NaHCO}_{3}(4 \mathrm{~mL})$ and brine $(4 \mathrm{~mL})$ and dried with anhydrous $\mathrm{Na}_{2} \mathrm{SO}_{4}$. The solvent was evaporated off to give 6 in white foam. The product was eluted with 0-5\% methanol in a solvent mixture of $\mathrm{Et}_{3} \mathrm{~N}$ and $\mathrm{CH}_{2} \mathrm{Cl}_{2}\left(0.1: 99.9\right.$, v/v). Yield: $133 \mathrm{mg}(68 \%) . \mathrm{R}_{\mathrm{f}}: 0.64,0.73\left(\mathrm{CH}_{2} \mathrm{Cl}_{2^{-}}\right.$ $\left.\mathrm{CH}_{3} \mathrm{OH}, 19: 1\right) ;{ }^{31} \mathrm{P}-\mathrm{NMR}\left(\mathrm{CDCl}_{3}\right): \delta 149.5,149.2$. ESI-MS: $m / z 863.1[\mathrm{M}+\mathrm{H}]^{+}$.

\section{5'-O-(4,4'-dimethoxytrityl)-2- $N$-(phenoxyacetyl)-8-oxo-7,8-dihydro-2'-} deoxyguanosine-3'-O-[(2-cyanoethyl)- $N, N$-diisopropyl-phosphoramidite] (7)— Compound 7 was prepared following the previously published procedures (Details shown in the Supporting Information) (37-39).

\section{ODN Synthesis}

ODNs (sequences shown in Table 1) were synthesized on a Beckman Oligo 1000S DNA synthesizer (Fullerton, CA) at 1- $\mu$ mol scale. The phosphoramidite building blocks 6 and 7 were dissolved in anhydrous acetonitrile at a concentration of $0.06 \mathrm{M}$, ultramild phosphoramidite building blocks (Glen Research Inc., Sterling, VA) of dG, dC and dA were employed, and the factory-installed ODN assembly protocol was used without any modification. After synthesis, the products were cleaved from the controlled-pore glass (CPG) support and deprotected with $30 \% \mathrm{NH}_{4} \mathrm{OH}$ at room temperature for $1.5 \mathrm{~h}$. The ODNs were then purified by reversed-phase HPLC.

\section{Thermodynamic Studies}

UV absorbance-versus-temperature profiles were recorded on a Varian Cary 50 spectrophotometer (Varian Inc., Palo Alto, CA), and the ODNs were dissolved in a 1.2-mL solution containing $250 \mathrm{mM} \mathrm{NaCl}, 10 \mathrm{mM}$ sodium cacodylate, and $0.1 \mathrm{mM}$ EDTA (pH 7.0) at a total ODN concentration $\left(C_{\mathrm{t}}\right)$ of $2.0,3.4,5.6,9.5$, or $16 \mu \mathrm{M}$. The absorbance was recorded in the reverse and forward directions for a temperature range of $80-10^{\circ} \mathrm{C}$ at a rate of $1{ }^{\circ} \mathrm{C} / \mathrm{min}$, and the melting temperature $\left(T_{\mathrm{m}}\right)$ value was obtained by the derivative method.

The thermodynamic parameters were obtained from the van't Hoff plot (40), in which the reciprocal of Tm was plotted against $\ln \frac{C t}{4}$ :

$$
\frac{1}{T m}=\left(\frac{R}{\Delta H^{\circ}}\right) \ln \frac{C t}{4}+\frac{\Delta S^{\circ}}{\Delta H^{\circ}}
$$

and

$$
\Delta G^{\circ}=\Delta H^{\circ}-T \Delta S^{\circ}
$$

where $\mathrm{R}$ is the ideal gas constant $\left(=1.987 \mathrm{cal} \mathrm{mol}^{-1} \mathrm{~K}^{-1}\right)$. The error limits for $\Delta G^{\circ}, \Delta H^{\circ}$ and $\Delta S^{\circ}$ derived from fitted parameters were calculated by using previously described equations (41-43). 


\section{Results}

\section{Synthesis of Phosphoramidite Building Blocks for the Dual Incorporation of Tg and 8-oxodG into ODNs}

Phosphoramidite building blocks of both Tg and 8-oxodG are commercially available (Glen Research). The labile nature of thymidine glycol, which was shown to be decomposed upon treatment with concentrated ammonia at room temperature for extended period of time (33), prevents the use of the commercially available building block of 8-oxodG, which necessitates deprotection with concentrated ammonia at room temperature for $24-48 \mathrm{~h}$, for the dual insertion of the two oxidatively damaged products into ODNs. In addition, the 5- and 6-hydroxyl groups in the commercially available Tg building block were protected with TBDMS. The nucleobase deprotection of those ODNs that are synthesized with the Tg building block, therefore, requires treatments in two steps, one with ammonium hydroxide and the other with tetrabutyl ammonium fluoride (TBAF).

With the above analysis in mind, we decided to prepare the phosphoramidite building blocks of 8-oxo-dG, whose $\mathrm{N} 2$ is protected with a phenoxyacetyl group (37-39), and thymidine glycol, whose 5- and 6-dihydroxyl groups were protected with acetyl functionality. The latter protection of thymidine glycol obviates the needs for the deprotection with TBAF.

To synthesize the thymidine glycol phosphoramidite building block, we first protected the $3^{\prime}$ and 5' hydroxyl groups of thymidine with DMTr. The DMTr protecting group was chosen for its easy removal upon acid treatment and its strong UV absorbance, which allows for the monitoring of the elution of the poorly UV-absorptive Tg during flash column chromatography separation. The DMTr-protected compound was then oxidized with $\mathrm{OsO}_{4}$ to offer the desired thymidine glycol (33). We then protected both hydroxyl groups in thymine glycol with acetyl groups, which was achieved by using DMAP as a catalyst (44). It is worth noting that the acetylation of the tertiary hydroxyl group was not complete without the addition of DMAP. This result is in line with what Gasparutto et al. (35) observed, where they showed that the protection of the 5-hydroxyl group of thymidine glycol with levulinyl functionality was incomplete. The resulting compound was treated with $70 \%$ acetic acid to give the 5,6-O-acetylthymidine glycol, which was converted to the phosphoramidite building block using published procedures (45).

With these two building blocks, we synthesized several ODNs (sequences listed in Table 1). We found that the acetyl protecting group of thymidine glycol can be readily removed upon treatment with $30 \% \mathrm{NH}_{4} \mathrm{OH}$ at room temperature for $1.5 \mathrm{~h}$ and thymidine glycol remains intact after such treatment. The ODNs were then purified by reversed-phase HPLC (HPLC traces are shown in the Supporting Information). It is worth noting that the C6 position of the thymidine glycol functionality undergoes epimerization during the deprotection step $(34,46)$. Therefore, we expect that both the $(5 \mathrm{R}, 6 \mathrm{~S})$ and the $(5 \mathrm{R}, 6 \mathrm{R})$ isomers are present in the ODN, though only the major isomer of the thymidine glycol, i.e., the $(5 \mathrm{R}, 6 \mathrm{~S})$ isomer, from the $\mathrm{OsO}_{4}$ oxidation was employed for phosphoramidite building block synthesis.

\section{ESI-MS and MS/MS Characterization of ODNs Containing Both 8-oxodG and Tg}

We next characterized the above ODNs by ESI-MS and MS/MS (Table 1, Figures 1-2 and Supporting Information). Here we began our discussion with the characterizations of $d$ (ATG*GCGTgGCTAT) (ODN5, G* represents 8-oxodG). In this regard, ESI-MS shows that the deconvoluted mass of the ODN is 50 Da higher than the calculated mass of the unmodified d(ATGGCGTGCTAT) (Figure 1a), which is consistent with the presence of both Tg and 8oxo-dG in this substrate. 
The product-ion spectrum of the $[\mathrm{M}-3 \mathrm{H}]^{3-}$ ion $(\mathrm{m} / \mathrm{z} 1240.7$, Figure $1 \mathrm{~b})$ of the ODN showed the formation of $\mathrm{w}_{\mathrm{n}}$ ions, i.e., $\mathrm{w}_{3}, \mathrm{w}_{4}, \mathrm{w}_{5}{ }^{2-}, \mathrm{w}_{6}{ }^{2-}, \mathrm{w}_{7}{ }^{2-}, \mathrm{w}_{8}{ }^{2-}$, and $\mathrm{w}_{11^{3-}}$, and $\left[\mathrm{a}_{\mathrm{n}}-\mathrm{Base}\right]$ ions, i.e., $\left[\mathrm{a}_{4}-\mathrm{Gua}\right],\left[\mathrm{a}_{5}-\mathrm{Cyt}\right],\left[\mathrm{a}_{6}-\mathrm{Gua}\right],\left[\mathrm{a}_{8}-\mathrm{Gua}\right]^{2-},\left[\mathrm{a}_{9}-\mathrm{Cyt}\right]^{2-}$ and $\left[\mathrm{a}_{11}-\mathrm{Ade}\right]^{2-}$ ions

[nomenclature for fragment ions follows that reported by McLuckey et al. (47); "Ade", "Cyt" and "Gua" represent adenine, cytosine and guanine, respectively]. Whereas the measured masses for the $\mathrm{w}_{3}, \mathrm{w}_{4}$, and $\mathrm{w}_{5}{ }^{2-}$ ions are the same as the calculated masses for the corresponding ions of the unmodified ODN, the $\mathrm{w}_{6}{ }^{2-}, \mathrm{w}_{7}{ }^{2-}$ and $\mathrm{w}_{8}{ }^{2-}$ ions exhibited 34 Da higher, and the $\mathrm{w}_{113}$ - ion showed $50 \mathrm{Da}$ higher, in mass than the corresponding fragments formed from the unmodified d(ATGGCGTGCTAT). These results are consistent with the presence of 8-oxo$\mathrm{dG}$ and $\mathrm{Tg}$ at the third and seventh positions in the ODN, respectively. The above conclusion is further substantiated by the observed masses for the [ $\mathrm{a}_{\mathrm{n}}$ - Base] ions. In this respect, the measured masses for the [a $\left.\mathrm{a}_{4}-\mathrm{Gua}\right],\left[\mathrm{a}_{5}-\mathrm{Cyt}\right]$ and $\left[\mathrm{a}_{6}-\mathrm{Gua}\right]$ ions are $16 \mathrm{Da}$ higher, whereas the measured masses of the $\left[\mathrm{a}_{8}-\mathrm{Gua}\right]^{2-},\left[\mathrm{a}_{9}-\mathrm{Cyt}\right]^{2-}$ and $\left[\mathrm{a}_{11}-\mathrm{Ade}\right]^{2-}$ ions are $50 \mathrm{Da}$ higher, than the calculated masses of the corresponding fragments from the unmodified $d$ (ATGGCGTGCTAT). It is worth noting that we did not observe the [ $\mathrm{a}_{3}$ - Base] and $\mathrm{w}_{9}$ ion (Figure 1b), which is consistent with previous findings about the fragmentations of ODNs containing a 8-oxodG (48).

The sequences of ODN3 and ODN4 were also confirmed by the similar ESI-MS and MS/MS analysis (Figure 2 shows the MS and MS/MS for ODN3, and the mass spectrometric results for ODN4 are shown in the Supporting Information). First of all, the measured masses of these two ODNs are consistent with their calculated masses (Table 1). In addition, the production spectrum of the $[\mathrm{M}-3 \mathrm{H}]^{3-}$ ion of ODN3 (Figure 2b) showed that the $\mathrm{w}_{7}{ }^{2-}, \mathrm{w}_{8}{ }^{2-}, \mathrm{w}_{9}{ }^{3-}, \mathrm{w}_{11}{ }^{3-}$, $\left[\mathrm{a}_{8}-\mathrm{Gua}\right]^{2-},\left[\mathrm{a}_{9}-\mathrm{Cyt}\right]^{2-}$ and $\left[\mathrm{a}_{11}-\mathrm{Ade}\right]^{2-}$ ions are $50 \mathrm{Da}$ higher in mass than the calculated masses for the corresponding ions of the unmodified ODN. The measured masses of $\mathrm{w}_{3}, \mathrm{w}_{4}$, $\mathrm{w}_{5},\left[\mathrm{a}_{3}-\mathrm{Gua}\right.$ ], [a $\mathrm{a}_{4}-\mathrm{Gua}$ ] and $\left[\mathrm{a}_{5}-\mathrm{Cyt}\right.$ ] ions, however, are the same as the calculated masses for the respective ions of the unmodified ODN. The product-ion spectrum of the $[\mathrm{M}-3 \mathrm{H}]^{3-}$ ion of ODN4 is very similar to that of ODN4 except that the [a $a_{6}-143$ ], a characteristic ion for short ODNs carrying a Tg (49), and $\mathrm{w}_{6}{ }^{2-}$ ions are found in the product-ion spectrum of ODN4 (Figure S15b), but undetectable in that of ODN3 (Figure 2b). Furthermore, the $\mathrm{w}_{5}$ ion is observed for ODN3 (Figure 2b), but not for ODN4 (Figure S15b).

\section{Thermodynamic Studies}

We next measured the thermodynamic parameters for duplex formation with the synthesized lesion-bearing substrates. The specific nucleotide sequences were: strand 1, 5'-

ATGGCXYGCTAT-3'; strand 2, 5'-ATAGCMNGCCAT-3', where XY/MN represents GT/ AC, GT/AA, TG/CA, G*T/AC, G*T/AA, GTg/AC, G*Tg/AC, G*Tg/AA or TgG*/CA (G* represents 8-oxodG). We refer to the duplexes by abbreviations of the form of XY/MN (Table 2). We determined the $\Delta H$ and $\Delta S$ by fitting $T_{m}{ }^{-1}$ versus $\ln \left(C_{t} / 4\right)$ as shown in Figure 3 (Data for unmodified and single base lesion-bearing ODNs are shown in the Supporting Information). The $\Delta H, \Delta S, \Delta G_{25^{\circ} \mathrm{C}}$, and the $T_{m}$ values at $C_{t}=16.0 \mu \mathrm{M}$ are listed in Table 2.

Our data on thermodynamic parameters (Table 2) showed that the free energy change associated with the formation of duplex at $25{ }^{\circ} \mathrm{C}\left(\Delta G_{25}{ }^{\circ} \mathrm{C}\right)$ with 8 -oxodG/dA base pair $(-15.1$ $\mathrm{kcal} / \mathrm{mol})$ is very similar to that for the formation of the duplex with 8 -oxodG/dC base pair $(-15.3 \mathrm{kcal} / \mathrm{mol})$. These results are consistent with previous thermodynamic results as well as NMR and X-ray crystal structure studies (50-52), which showed that 8-oxodG can form base pairs with both $\mathrm{dC}$ and $\mathrm{dA}$, depending on whether the damaged nucleoside adopts an anti or syn configuration about the glycosidic bond $(50,51)$.

Consistent with previous thermodynamic studies (34), our results showed that the presence of thymine glycol decreases markedly the duplex stability and it preferentially forms base pairing with adenine. In addition, duplex ODN with tandem lesion is less stable than the corresponding 
duplex with either of the two single-base lesions alone (Table 2). Moreover, there is no obvious difference in thermal stability of duplex ODNs with the two types of tandem lesions, i.e., 5'$\mathrm{G}^{*} \mathrm{Tg}-3^{\prime}$ and $5^{\prime}-\mathrm{TgG}^{*}-3^{\prime}$ (Duplexes 7 and 9, Table 2).

\section{Discussion}

In the present work, we successfully synthesized phosphoramidite building blocks of thymidine glycol and 8-oxodG, which facilitate the simultaneous insertion of the two lesions into ODNs. Additionally, with the use of acetyl group for the protection of the hydroxyl functionalities on the thymine glycol moiety, post-synthesis deprotection can be achieved in one step. The availability of authentic ODN substrates enables the assessment of the formation of this type of tandem lesions under various oxidative stress conditions. In this respect, the tandem lesioncarrying ODN substrates will facilitate the design and optimization of enzymatic digestion procedures for the successful release of this type of tandem lesion from duplex DNA.

Methylation of cytosine at $\mathrm{CpG}$ sites plays an important role in the epigenetic silencing of genes in mammalian cells $(53,54)$. Damage occurring at $\mathrm{CpG}$ dinucleotide and the resulting mutation at these sites may perturb the binding of DNA to methyl-CpG binding proteins (55). We reason that the type of tandem lesion that we synthesized here may have implications in CpG mutagenesis. In this context, under oxidative stress, $\mathrm{mC}$ could be damaged to form 5methylcytosine glycol (56), which is susceptible to deamination to yield thymine glycol. On the other hand, the $\mathrm{dG}$ at $\mathrm{CpG}$ site can be oxidized to give a 8-oxodG (Scheme 2). Thymidine glycol is mostly a blocking lesion. It, however, can be bypassed by translesion synthesis DNA polymerases including yeast DNA polymerases $\eta$ and $\zeta$ as well as human DNA polymerase $\kappa$, and all three polymerases preferentially insert a dA opposite the lesion $(5,57,58)$. On the other hand, 8-oxodG can be bypassed by various DNA polymerases and both $\mathrm{dC}$ and $\mathrm{dA}$ can be inserted opposite the lesion $(59,60)$. Therefore, the tandem lesions with a pyrimidine glycol being neighboring to 8-oxodG may contribute to the previously observed ROS-induced $\mathrm{mCG} \rightarrow \mathrm{TT}$ mutation (61). The availability of ODN substrates bearing structurely defined tandem lesions will allow for the replication studies of these lesions both in vitro and in vivo, which may offer important insights into the roles of this type of lesions in $\mathrm{CpG}$ mutagenesis.

Recent repair studies on cluster lesions showed that the repair of one lesion can be hampered by the presence of another lesion nearby $(25-28,31)$. Our thermodynamic measurement results clearly showed that tandem lesions, where an 8-oxodG is adjacent to a Tg, can cause more destabilization to DNA duplexes than either of the two lesions alone. In this regard, the presence of Tg and 8-oxodG neighboring to each other destabilizes the duplex DNA by $\sim 5.1 \mathrm{kcal} / \mathrm{mol}$ (Table 2). Although either Tg or 8-oxodG, when present by itself, can be efficiently repaired by base excision repair (BER) enzymes (62), the elevated structural distortion caused by the vicinal single-base lesions may result in the compromised repair of these two lesions by BER machinery. In addition, both Tg and 8-oxodG could be excised from DNA by NER enzymes in vitro (63), the formation of these two lesions in tandem, due to the increased structural distortion, may also render the tandem lesions to be excised more efficiently by NER than while the two lesions are not proximal to each other. The availability of authentic ODN substrates will again enable us to examine such possibilities.

Taken together, we reported here for the first time the dual incorporation of $\mathrm{Tg}$ and 8-oxodG into ODNs. The availability of ODNs carrying neighboring 8-oxodG and Tg builds a solid foundation for examining the replication and repair of the tandem oxidative lesions.

\section{Supplementary Material}

Refer to Web version on PubMed Central for supplementary material. 


\section{Acknowledgement}

The authors want to thank the National Institutes of Health (CA 96906 and CA101864) for supporting this research.

\section{Abbreviations}

ROS, reactive oxygen species; ODN, oligodeoxynucleotides; BER, base excision repair; NER, nucleotide excision repair; ESI, electrospray ionization; MS, mass spectrometry; MS/MS, tandem mass spectrometry.

\section{References}

(1). Finkel T, Holbrook NJ. Oxidants, oxidative stress and the biology of ageing. Nature 2000;408:239247. [PubMed: 11089981]

(2). Dizdaroglu M, Jaruga P, Birincioglu M, Rodriguez H. Free radical-induced damage to DNA: mechanisms and measurement. Free Radic. Biol. Med 2002;32:1102-1115. [PubMed: 12031895]

(3). Halliwell B, Gutteridge JM. Role of free radicals and catalytic metal ions in human disease: an overview. Methods Enzymol 1990;186:1-85. [PubMed: 2172697]

(4). Hayes RC, Petrullo LA, Huang H, Wallace SS, LeClerc JE. Oxidative damage in DNA. Lack of mutagenicity by thymine glycol lesions. J. Mol. Biol 1988;201:239-246. [PubMed: 3418701]

(5). Johnson R,E, Yu S-L, Prakash S, Prakash L. Yeast DNA polymerase zeta is essential for error-free replication past thymine glycol. Genes Dev 2003;17:77-87. [PubMed: 12514101]

(6). Seki M, Masutani C, Yang Lee W, Schuffert A, Iwai S, Bahar I, Wood Richard D. High-efficiency bypass of DNA damage by human DNA polymerase Q. EMBO J 2004;23:4484-4494. [PubMed: 15496986]

(7). Basu AK, Loechler EL, Leadon SA, Essigmann JM. Genetic effects of thymine glycol: site-specific mutagenesis and molecular modeling studies. Proc. Natl. Acad. Sci. USA 1989;86:7677-7681. [PubMed: 2682618]

(8). Clark JM, Beardsley GP. Thymine glycol lesions terminate chain elongation by DNA polymerase I in vitro. Nucleic Acids Res 1986;14:737-749. [PubMed: 3511447]

(9). Ide H, Kow YW, Wallace SS. Thymine glycols and urea residues in M13 DNA constitute replicative blocks in vitro. Nucleic Acids Res 1985;13:8035-8052. [PubMed: 3906566]

(10). Wagner J, Kamiya H, Fuchs RPP. Leading versus lagging strand mutagenesis induced by 7,8dihydro-8-oxo-2'-deoxyguanosine in Escherichia coli. J. Mol. Biol 1997;265:302. [PubMed: 9018044]

(11). Tan X, Grollman AP, Shibutani S. Comparison of the mutagenic properties of 8-oxo-7,8-dihydro-2'deoxyadenosine and 8-oxo-7,8-dihydro-2'-deoxyguanosine DNA lesions in mammalian cells. Carcinogenesis 1999;20:2287-2292. [PubMed: 10590221]

(12). Box HC, Budzinski EE, Freund HG, Evans MS, Patrizyc HB, Wallace JC, Maccubbin AE. Vicinal lesions in x-irradiated DNA? Int. J. Radiat. Biol 1993;64:261-263. [PubMed: 8105004]

(13). Box HC, Budzinski EE, Dawidzik JD, Wallace JC, Evans MS, Gobey JS. Radiation-induced formation of a crosslink between base moieties of deoxyguanosine and thymidine in deoxygenated solutions of d(CpGpTpA). Radiat. Res 1996;145:641-643. [PubMed: 8619032]

(14). Budzinski EE, Dawidzik JB, Rajecki MJ, Wallace JC, Schroder EA, Box HC. Isolation and characterization of the products of anoxic irradiation of d(CpGpTpA). Int. J. Radiat. Biol 1997;71:327-336. [PubMed: 9134023]

(15). Bourdat AG, Douki T, Frelon S, Gasparutto D, Cadet J. Tandem base lesions are generated by hydroxyl radical within isolated DNA in aerated aqueous solution. J. Am. Chem. Soc 2000;122:4549-4556.

(16). Bellon S, Ravanat JL, Gasparutto D, Cadet J. Cross-linked thymine-purine base tandem lesions: Synthesis, characterization, and measurement in gamma-irradiated isolated DNA. Chem. Res. Toxicol 2002;15:598-606. [PubMed: 11952347] 
(17). Liu Z, Gao Y, Wang Y. Identification and characterization of a novel cross-link lesion in d(CpC) upon 365-nm irradiation in the presence of 2-methyl-1,4-naphthoquinone. Nucleic Acids Res 2003;31:5413-5424. [PubMed: 12954778]

(18). Zhang Q, Wang Y. Independent generation of 5-(2'-deoxycytidinyl)methyl radical and the formation of a novel cross-link lesion between 5-methylcytosine and guanine. J. Am. Chem. Soc 2003;125:12795-12802. [PubMed: 14558827]

(19). Zhang Q, Wang Y. Independent generation of the 5-hydroxy-5,6-dihydrothymidin-6-yl radical and its reactivity in dinucleoside monophosphates. J. Am. Chem. Soc 2004;126:13287-13297. [PubMed: 15479083]

(20). Zhang Q, Wang Y. Generation of 5-(2'-deoxycytidyl)methyl radical and the formation of intrastrand cross-link lesions in oligodeoxyribonucleotides. Nucleic Acids Res 2005;33:1593-1603. [PubMed: 15767284]

(21). Budzinski EE, Dawidzik JD, Wallace JC, Freund HG, Box HC. The radiation chemistry of d (CpGpTpA) in the presence of oxygen. Radiat. Res 1995;142:107-109. [PubMed: 7899553]

(22). Goodhead DT. Initial events in the cellular effects of ionizing radiations: clustered damage in DNA. Int. J. Radiat. Biol 1994;65:7-17. [PubMed: 7905912]

(23). Jenner TJ, Fulford J, O’Neill P. Contribution of base lesions to radiation-induced clustered DNA damage: implication for models of radiation response. Radiat. Res 2001;156:590-593. [PubMed: 11604077]

(24). Sutherland BM, Bennett PV, Sidorkina O, Laval J. Clustered DNA damages induced in isolated DNA and in human cells by low doses of ionizing radiation. Proc. Natl. Acad. Sci. USA 2000;97:103-108. [PubMed: 10618378]

(25). Budworth H, Dianova II, Podust VN, Dianov GL. Repair of clustered DNA lesions. Sequencespecific inhibition of long-patch base excision repair by 8-oxoguanine. J. Biol. Chem 2002;277:21300-21305. [PubMed: 11923315]

(26). Budworth H, Dianov GL. Mode of inhibition of short-patch base excision repair by thymine glycol within clustered DNA lesions. J. Biol. Chem 2003;278:9378-9381. [PubMed: 12519757]

(27). Lomax M,E, Cunniffe S, O’Neill P. Efficiency of repair of an abasic site within DNA clustered damage sites by mammalian cell nuclear extracts. Biochemistry 2004;43:11017-11026. [PubMed: 15323560]

(28). Lomax ME, Cunniffe S, O'Neill P. 8-OxoG retards the activity of the ligase III/XRCC1 complex during the repair of a single-strand break, when present within a clustered DNA damage site. DNA Repair 2004;3:289-299. [PubMed: 15177044]

(29). Pearson CG, Shikazono N, Thacker J, O’Neill P. Enhanced mutagenic potential of 8-oxo-7,8dihydroguanine when present within a clustered DNA damage site. Nucleic Acids Res 2004;32:263-270. [PubMed: 14715924]

(30). Kalam MA, Basu AK. Mutagenesis of 8-oxoguanine adjacent to an abasic site in simian kidney cells: tandem mutations and enhancement of G-->T transversions. Chem. Res. Toxicol 2005;18:1187-1192. [PubMed: 16097791]

(31). Lomax ME, Salje H, Cunniffe S, O'Neill P. 8-OxoA inhibits the incision of an AP site by the DNA glycosylases Fpg, Nth and the AP endonuclease HAP1. Radiat. Res 2005;163:79-84. [PubMed: 15606310]

(32). Beaucage SL, Iyer RP. The synthesis of modified oligonucleotides by the phosphoramidite approach and their applications. Tetrahedron 1993;49:6123-6194.

(33). Iwai S. Synthesis of thymine glycol containing oligonucleotides from a building block with the oxidized base. Angew. Chem. Int. Ed 2000;39:3874-3876.

(34). Iwai S. Synthesis and thermodynamic studies of oligonucleotides containing the two isomers of thymine glycol. Chem.-Eur. J 2001;7:4343-4351.

(35). Gasparutto D, Cognet S, Roussel S, Cadet J. Synthesis of a convenient thymidine glycol phosphoramidite monomer and its site-specific incorporation into DNA fragments. Nucleosides, Nucleotides \& Nucleic Acids 2005;24:1831-1842.

(36). Sekine M, Hata T. 4,4',4"-Tris(benzoyloxy)trityl as a new type of base-labile group for protection of primary hydroxyl groups. J. Org. Chem 1983;48:3011-3014. 
(37). Bourdat A-G, Gasparutto D, Cadet J. Synthesis and enzymic processing of oligodeoxynucleotides containing tandem base damage. Nucleic Acids Res 1999;27:1015-1024. [PubMed: 9927734]

(38). Nampalli S, Kumar S. Efficient synthesis of 8-oxo-dGTP: A mutagenic nucleotide. Bioorg. Med. Chem. Lett 2000;10:1677-1679. [PubMed: 10937723]

(39). Gillet LCJ, Scharer OD. Preparation of C8-amine and acetylamine adducts of 2'-deoxyguanosine suitably protected for DNA synthesis. Org. Lett 2002;4:4205-4208. [PubMed: 12443059]

(40). Breslauer KJ. Extracting thermodynamic data from equilibrium melting curves for oligonucleotide order-disorder transitions. Methods Enzymol 1995;259:221-242. [PubMed: 8538456]

(41). Meyer, SL. Data Analysis for Scientists and Engineers. Wiley; New York: 1975.

(42). SantaLucia J Jr. Kierzek R, Turner DH. Functional group substitutions as probes of hydrogen bonding between GA mismatches in RNA internal loops. J. Am. Chem. Soc 1991;113:4313-4322.

(43). Persmark M, Guengerich FP. Spectroscopic and thermodynamic characterization of the interaction of N7-guanyl thioether derivatives of d(TGCTG*CAAG) with potential complements. Biochemistry 1994;33:8662-8672. [PubMed: 8038155]

(44). Hoefle G, Steglich W, Vorbrueggen H. New synthetic methods. 25. 4-Dialkylaminopyridines as acylation catalysts. 4 Puridine syntheses. 1. 4-Dialkylaminopuridines as highly active acylation catalysts. Angew. Chem 1978;90:602-615.

(45). Gait, MJ. Oligonucleotide Synthesis: A Practical Approach. IRL Press Limited; Oxford, England: 1984.

(46). Lustig MJ, Cadet J, Boorstein RJ, Teebor GW. Synthesis of the diastereomers of thymidine glycol, determination of concentrations and rates of interconversion of their cis-trans epimers at equilibrium and demonstration of differential alkali lability within DNA. Nucleic Acids Res 1992;20:48394845. [PubMed: 1408799]

(47). McLuckey SA, Van Berker GJ, Glish GL. Tandem mass spectrometry of small, multiply charged oligonucleotides. J. Am. Soc. Mass Spectrom 1992;3:60-70.

(48). Luo H, Lipton MS, Smith RD. Charge effects for differentiation of oligodeoxynucleotide isomers containing 8-oxo-dG residues. J. Am. Soc. Mass Spectrom 2002;13:195-199. [PubMed: 11908798]

(49). Wang Y. HPLC isolation and mass spectrometric characterization of two isomers of thymine glycols in oligodeoxynucleotides. Chem. Res. Toxicol 2002;15:671-676. [PubMed: 12018988]

(50). Kouchakdjian M, Bodepudi V, Shibutani S, Eisenberg M, Johnson F, Grollman AP, Patel DJ. NMR structural studies of the ionizing radiation adduct 7-hydro-8-oxodeoxyguanosine (8-oxo-7H-dG) opposite deoxyadenosine in a DNA duplex. 8-Oxo-7H-dG(syn).dA(anti) alignment at lesion site. Biochemistry 1991;30:1403-1412. [PubMed: 1991121]

(51). McAuley-Hecht KE, Leonard GA, Gibson NJ, Thomson JB, Watson WP, Hunter WN, Brown T. Crystal structure of a DNA duplex containing 8-hydroxydeoxyguanine-adenine base pairs. Biochemistry 1994;33:10266-10270. [PubMed: 8068665]

(52). Plum GE, Grollman AP, Johnson F, Breslauer KJ. Influence of the oxidatively damaged adduct 8xxodeoxyguanosine on the conformation, energetics, and thermodynamic stability of a DNA duplex. Biochemistry 1995;34:16148-16160. [PubMed: 8519772]

(53). Jones PA, Takai D. The role of DNA methylation in mammalian epigenetics. Science 2001;293:1068-1070. [PubMed: 11498573]

(54). Lorincz MC, Groudine M. CmC(a/t)GG methylation: A new epigenetic mark in mammalian DNA? Proc. Natl. Acad. Sci. USA 2001;98:10034-10036. [PubMed: 11526227]

(55). Valinluck V, Tsai H-H, Rogstad DK, Burdzy A, Bird A, Sowers LC. Oxidative damage to methyl$\mathrm{CpG}$ sequences inhibits the binding of the methyl-CpG binding domain (MBD) of methyl-CpG binding protein 2 (MeCP2). Nucleic Acids Res 2004;32:4100-4108. [PubMed: 15302911]

(56). Zuo S, Boorstein RJ, Teebor GW. Oxidative damage to 5-methylcytosine in DNA. Nucleic Acids Res 1995;23:3239-3243. [PubMed: 7667100]

(57). Kusumoto R, Masutani C, Iwai S, Hanaoka F. Translesion synthesis by human DNA polymerase eta across thymine glycol lesions. Biochemistry 2002;41:6090-6099. [PubMed: 11994004]

(58). Fischhaber PL, Gerlach VL, Feaver WJ, Hatahet Z, Wallace SS, Friedberg EC. Human DNA polymerase kappa bypasses and extends beyond thymine glycols during translesion synthesis in vitro, preferentially incorporating correct nucleotides. J. Biol. Chem 2002;277:37604-37611. [PubMed: 12145297] 
(59). Zhang Y, Yuan F, Wu X, Wang M, Rechkoblit O, Taylor J-S, Geacintov NE, Wang Z. Error-free and error-prone lesion bypass by human DNA polymerase kappa in vitro. Nucleic Acids Res 2000;28:4138-4146. [PubMed: 11058110]

(60). Zhang Y, Yuan F, Wu X, Taylor J-S, Wang Z. Response of human DNA polymerase iota to DNA lesions. Nucleic Acids Res 2001;29:928-935. [PubMed: 11160925]

(61). Lee D-H, O'Connor TR, Pfeifer GP. Oxidative DNA damage induced by copper and hydrogen peroxide promotes CG TT tandem mutations at methylated $\mathrm{CpG}$ dinucleotides in nucleotide excision repair-deficient cells. Nucleic Acids Res 2002;30:3566-3573. [PubMed: 12177298]

(62). Fromme JC, Verdine GL. Base excision repair. Adv. Protein Chem 2004;69:1-41. [PubMed: 15588838]

(63). Reardon JT, Bessho T, Kung HC, Bolton PH, Sancar A. In vitro repair of oxidative DNA damage by human nucleotide excision repair system: possible explanation for neurodegeneration in xeroderma pigmentosum patients. Proc. Natl. Acad. Sci. USA 1997;94:9463-9468. [PubMed: 9256505] 


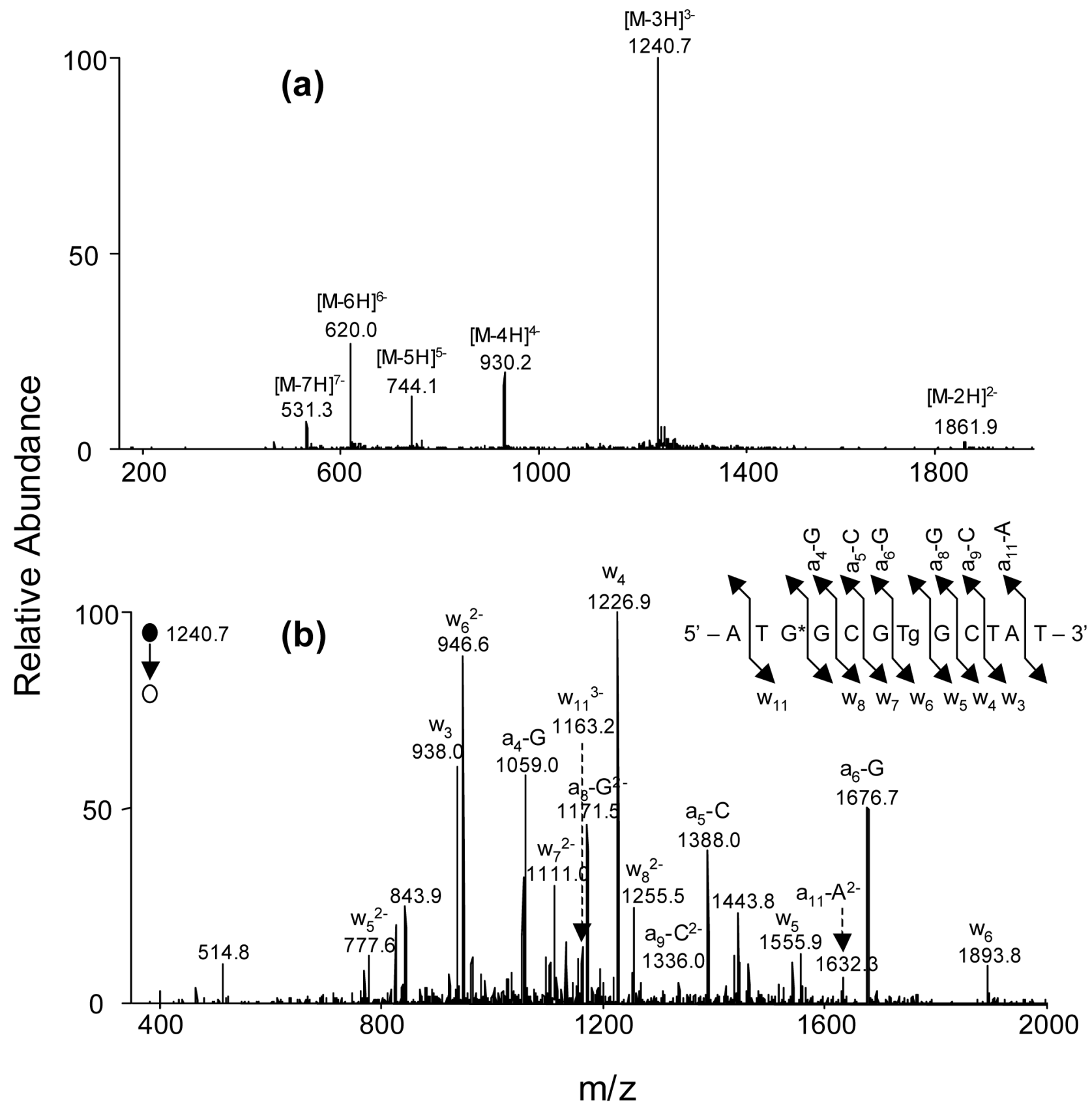

Figure 1.

ESI-MS \& MS/MS characterizations of d(ATG*GCGTgGCTAT): (a) Negative-ion ESI-MS; (b) product-ion spectrum of the $[\mathrm{M}-3 \mathrm{H}]^{3-}$ ion $(\mathrm{m} / \mathrm{z} 1241)$. 


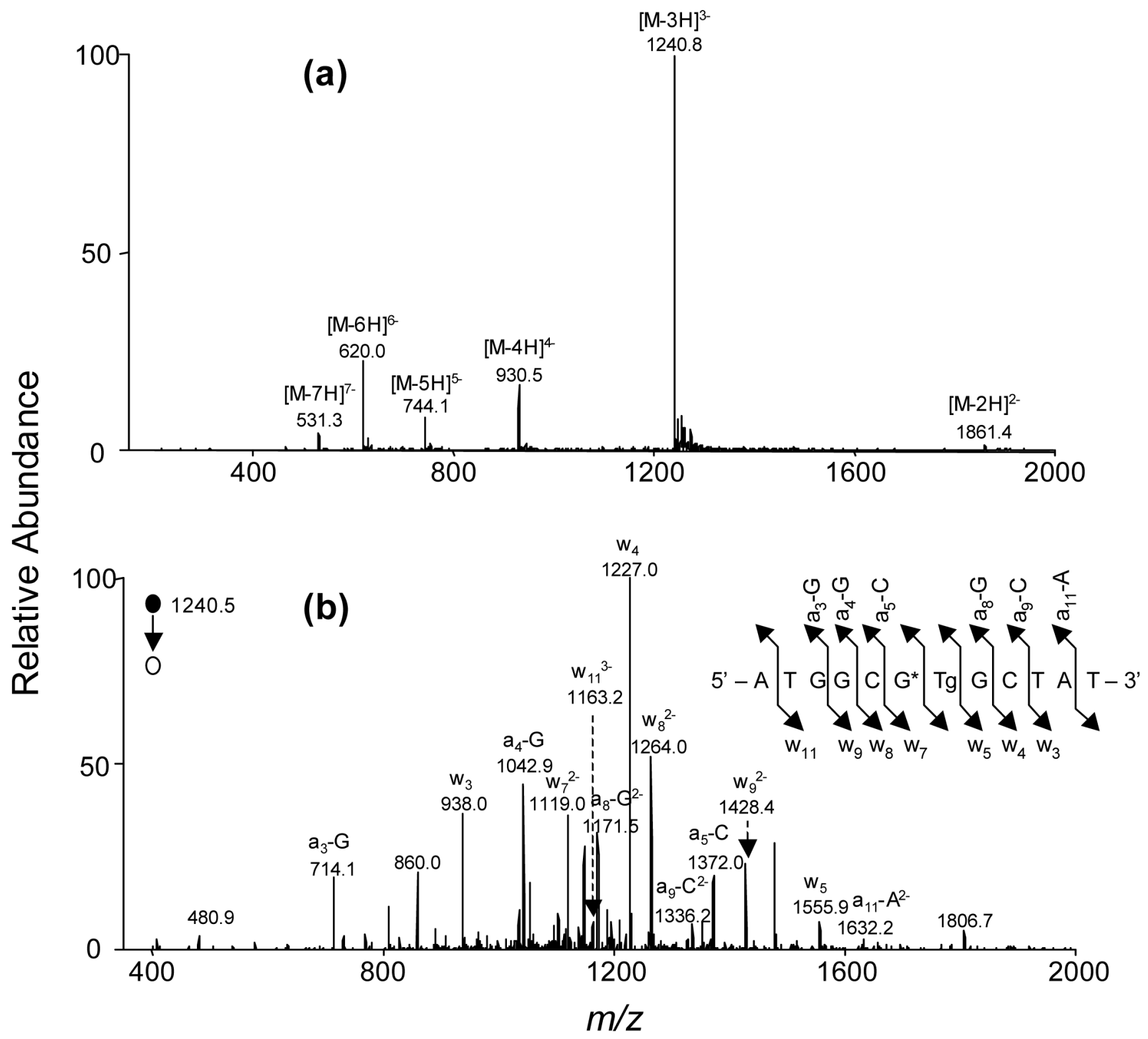

Figure 2.

ESI-MS \& MS/MS characterizations of d(ATGGCG*TgGCTAT): (a) Negative-ion ESI-MS;

(b) product-ion spectrum of $[\mathrm{M}-3 \mathrm{H}]^{3-}$ ion $(\mathrm{m} / \mathrm{z}$ 1241). 


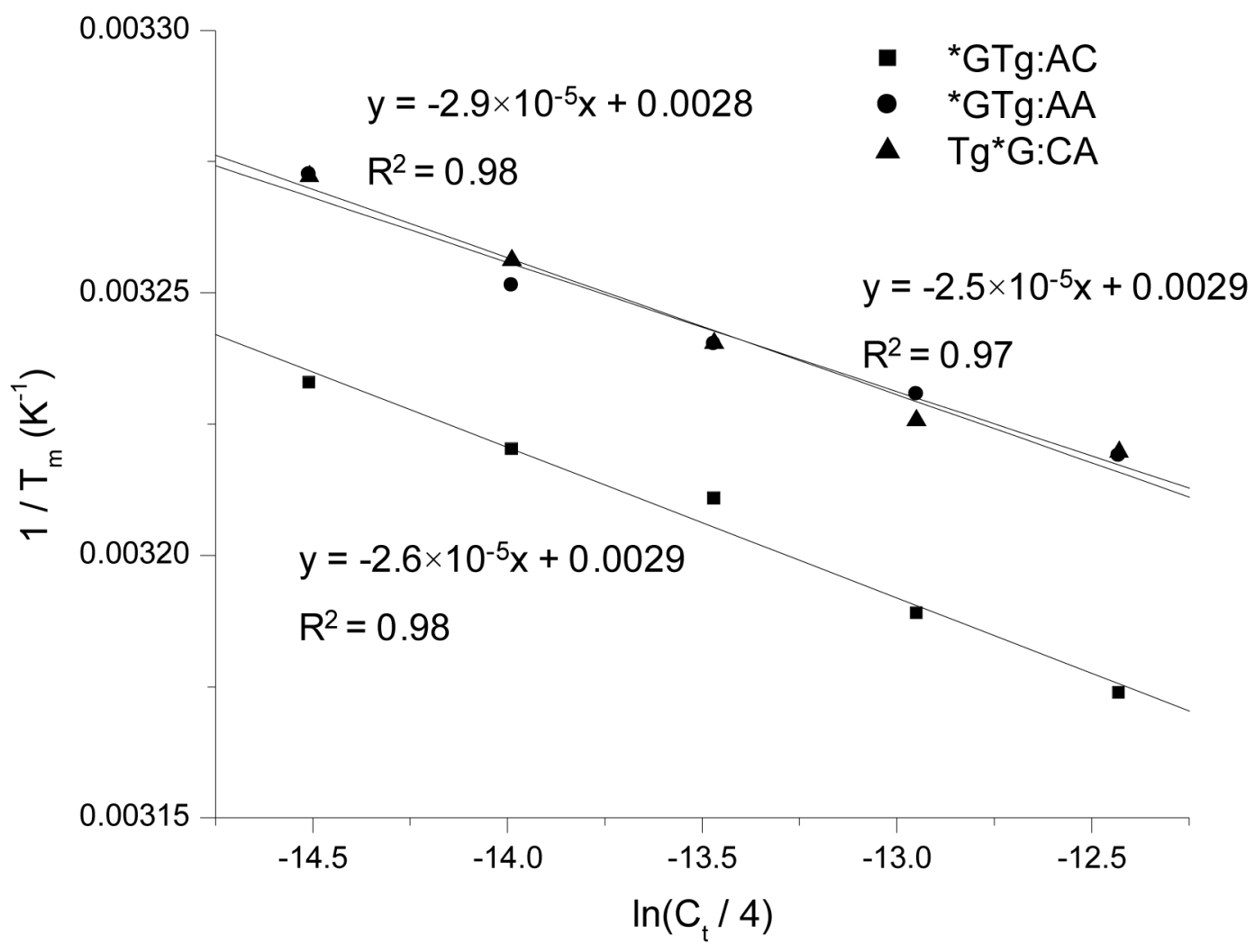

Figure 3.

Plots of $1 / T_{m}$ vs. $\ln \left(C_{t} / 4\right)$ for the duplexes containing thymidine glycol and 8-oxodG tandem lesions. The duplex is d(ATGGCXYGCTAT)/d(ATAGCMNGCCAT), where XY/MN represents $\mathrm{G}^{*} \mathrm{Tg} / \mathrm{AC}(\boldsymbol{\bullet}), \mathrm{G}^{*} \mathrm{Tg} / \mathrm{AA}(\bullet), \mathrm{TgG} * \mathrm{CA}($ ). 
<smiles>CCOCC1OC(N2C(=O)NC(=O)C(C)(O)C2O)CC1O[18O]C(C)(C)C</smiles>

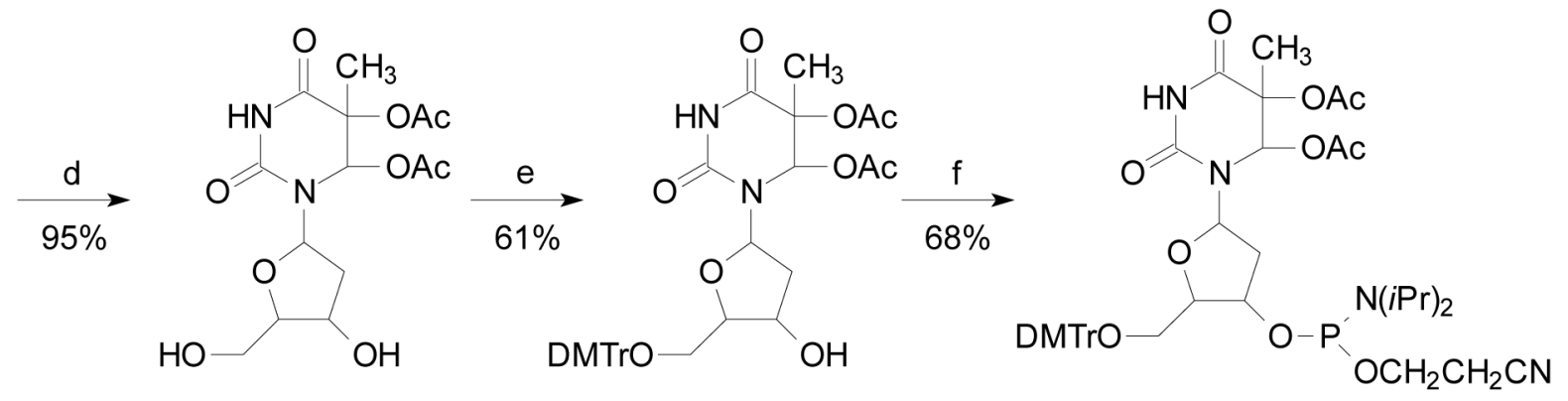

Scheme 1.

Synthesis of phosphoramidite building block of $\mathrm{Tg}$.

Reagents: (a) DMTrCl/Pyridine/70 ${ }^{\circ} \mathrm{C}$; (b) $\mathrm{OsO}_{4} / \mathrm{Pyridine}$; (c) $\mathrm{Ac}_{2} \mathrm{O} / \mathrm{DMAP} /$ Pyridine; (d) $70 \%$ acetic acid; (e) DMTrCl/Pyridine; (f) $\mathrm{NC}\left(\mathrm{CH}_{2}\right)_{2} \mathrm{OP}(\mathrm{Cl}) \mathrm{N}(i \mathrm{Pr})_{2} / \mathrm{DIEA} / \mathrm{CH}_{2} \mathrm{Cl}_{2}$ 


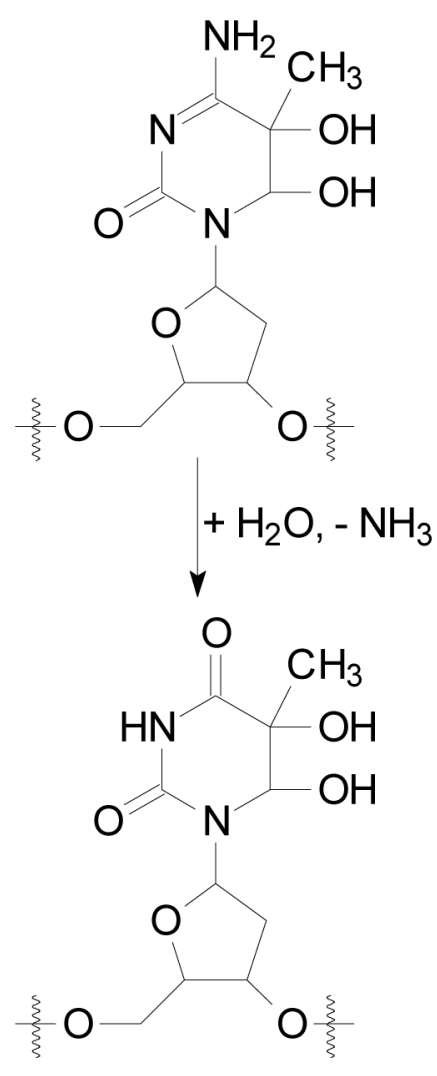

Scheme 2.

Deamination of 5-methycytosine glycol and the implications of tandem lesions in $\mathrm{mCG} \rightarrow \mathrm{TT}$ mutation.

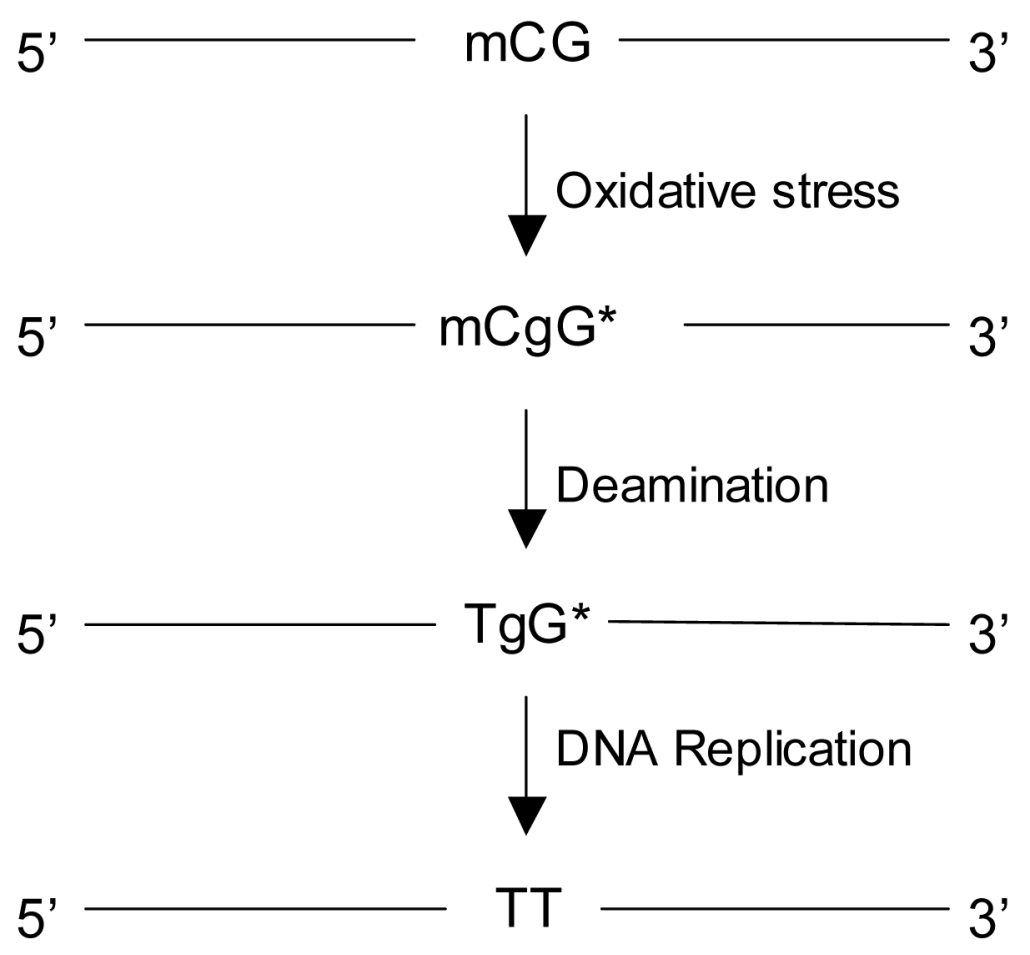


Table 1

Sequences of Synthesized Oligodeoxynucleotides

\begin{tabular}{|c|c|c|c|}
\hline ODNs & Sequence & Observed $m / z$ & Theoretical $m / z$ \\
\hline ODN1 & $5^{\prime}$-ATG GC ${ }^{*}$ TGC TAT-3' & 3691.2 & 3691.6 \\
\hline ODN2 & 5'-ATG GCG TgGC TAT-3' & 3709.2 & 3709.6 \\
\hline ODN3 & $5^{\prime}$-ATG GC ${ }^{*}$ TgGC TAT- $3^{\prime}$ & 3725.2 & 3725.6 \\
\hline ODN4 & $5^{\prime}$-ATG GCTg $G^{*}$ GC TAT-3' & 3724.9 & 3725.6 \\
\hline ODN5 & $5^{\prime}-\mathrm{AT}^{*}$ GCG TgGC TAT- $3^{\prime}$ & 3725.2 & 3725.6 \\
\hline
\end{tabular}




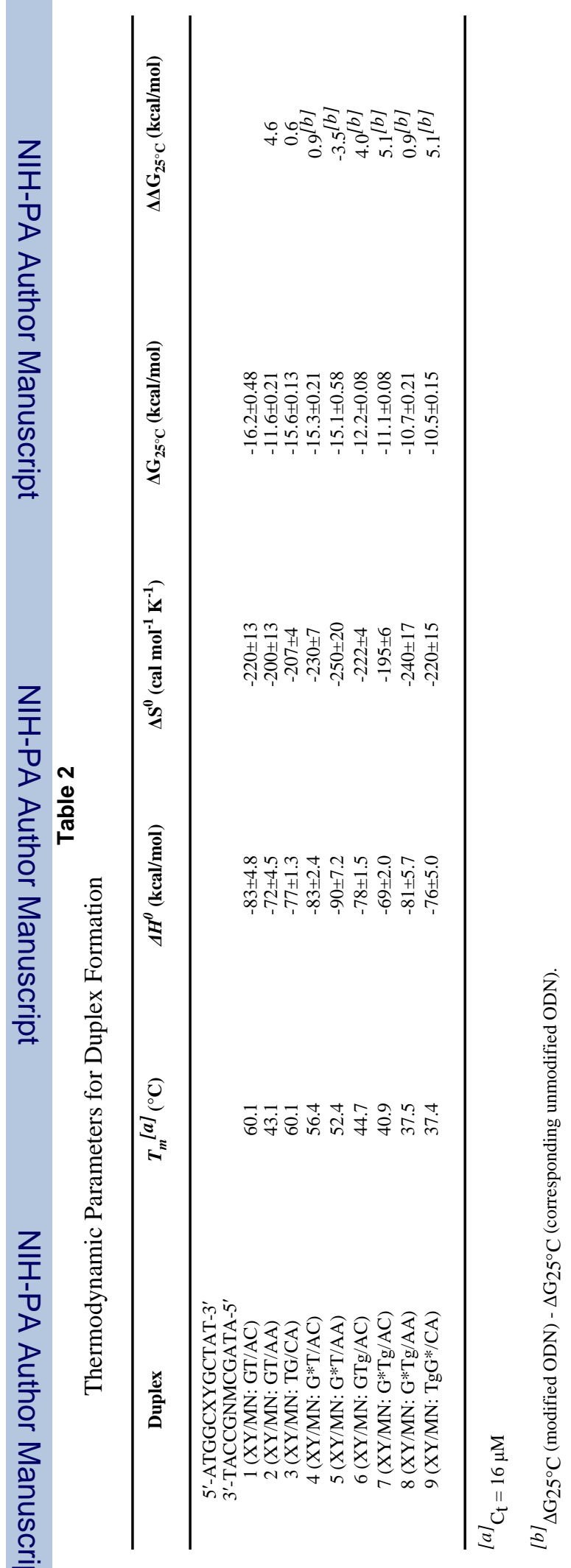

